\title{
The Middle East and North Africa
}

\author{
Omar S. Dahi \\ Assistant Professor of Economics \\ School of Social Science \\ Hampshire College \\ Amherst, MA 01002 \\ Firat Demir \\ Assistant Professor of Economics \\ Department of Economics \\ Hester Hall, 729 Elm Avenue \\ University of Oklahoma \\ Norman, OK 73019
}

In A.K. Dutt and J. Ros (Eds.), International Handbook of Development Economics Vol.2 (pp.522-535). Edward Elgar, 2008

\section{Introduction}

The growth and development performance of the Middle East and North Africa (MENA) region presents one of the major anomalies that current economics literature seeks to resolve, which is how to reconcile the existence of massive natural resources with the high unemployment, low growth and the general underdevelopment of the region. In this debate, much attention is focused on the problems arising from: a) state oriented inward looking economic policies, b) lack of 'integration' with the world economy, c) underdeveloped financial sectors and chilling investment climate, and d) low levels of human capital development. In this paper, we attempt to present a summarized yet more balanced and hopefully more insightful analysis of the growth and development experience of the countries in the region with a special attention given to the existing bottlenecks hindering future development prospects.

While discussing the MENA region as a whole we will divide the countries into five subgroups: 1) oil rich labor importing states (Bahrain, Kuwait, Oman, Libya, the United Arab Emirates, Qatar, and Saudi Arabia) 2) oil rich labor abundant states (Algeria, the Islamic Republic of Iran, Iraq, Syria), 3) oil poor labor abundant NICs (Egypt, Morocco, Turkey), 4) oilpoor limited natural resource states (Israel, Tunisia, West Bank and Gaza, Jordan, Lebanon) ${ }^{\mathrm{i}}$, and 5) natural resource poor states (Sudan, Yemen). (Richards and Waterbury, 1996) ${ }^{i i}$. Although the inclusion of Turkey, Israel, and Iran is controversial as the trajectory of the Arab and other Middle Eastern countries constitute a more appropriate whole, they share many commonalities as well. However, unless stated otherwise, the general statements will exclude Turkey and Israel.

The economic history of MENA region is characterized by several cycles of growth and accumulation. In retrospect, the region formerly enjoyed higher levels of economic development and prosperity compared to its counterparts in Europe. While Istanbul with its 700,000 inhabitants in $16^{\text {th }}$ century was the largest city in the world, North Africa overall was much more urbanized than Europe (Paris with 125,000 inhabitants vs. Cairo with 450,000 around 1500) (Bairoch, 1997:517-537). However, in the last of these cycles, the region experienced a decline in its growth and development indicators starting from early $18^{\text {th }}$ century with the factors that precipitated this decline remaining a source of continuing debate. ${ }^{\text {iii }}$ The current essay will focus 
on its most recent cycle namely that of after 1950s following the gaining of political independence and control over the natural resources by the countries in the region.

\section{Growth and Development in MENA}

From the late 1950s to the late 1970s (and in some cases, till late 80s and early 90s) the economic structure of the region was characterized by an Import Substituting Industrialization (ISI) regime, the main features of which (as elsewhere) included strict quantitative controls on international trade, overvalued exchange rates, and severe rationing in foreign exchange and credit markets.

Following the hikes in petroleum prices in the early 70s, growth and development indicators in the MENA region improved rapidly. The sudden increase in investment and growth rates in the oil-exporting countries spread to the rest of the region through increases in worker remittances, and capital flows. In addition, gross capital formation jumped to exceptionally high rates generating a locomotive effect on growth rates and overall standards of living. On the financial front, considerable amount of financial savings were accumulated abroad resulting in the famous expansion of euro-dollar market through the recycling of petro-dollars.

In contrast, the downside of the above picture has been the high level of volatility of GDP growth since the 1970s: the average volatility of GDP growth in the region as a whole has been twice that of developing country average and twice more volatile in the oil-rich economies than the rest of the region (Abed and Davoodi, 2003; Hirata, Kim and Kose, 2004: 62-63).

The single most important determinant of growth in MENA (where fuel products account for about half of the region's GDP and around 90 percent of total exports in the oil rich countries) has been the fluctuations in international oil prices. In addition to growth volatility, as a result of high dependence on oil revenues, fiscal policy in the oil rich countries is also volatile and pro-cyclical. Likewise, the oil-poor labor abundant countries are also oil price sensitive because a large part of their economies is dependent on worker remittances as well as on development aid and tourism revenues from the oil-rich labor poor countries. The non-oil producing sectors, on the other hand, suffer from Dutch-disease where the continuous flow of large oil revenues result in an appreciation of the real exchange rate making it less competitive.

In large part due to the collapse in oil prices in the 1980s and 1990s growth rates in the region experienced marked declines. Low growth rates failed to provide rapidly expanding labor force with sufficient employment opportunities and led to a deterioration of living standards and a rise in poverty rates. As a result, growth performance, GDP per worker, and total factor productivity levels in the MENA region since the early 1980s has been near zero and negative, closer to Latin America and lagging far behind East Asia. Furthermore, despite substantial improvements since the gaining of political independence, the region lags behind both East Asia and Latin America in the UN Human Development index (i.e. in adult illiteracy rate, life expectancy at birth etc.) (Bosworth and Collins, 2003; UNDP, 2002).

Nevertheless, there is considerable heterogeneity in performance across countries within the region. While the per capita incomes of the oil producing countries declined at an average annual rate of -0.79 percent between $1980-2000$, those in the non-oil producing countries increased by around 2 percent over the same period. Looking at the oil boom years we get a similar picture where non-oil producing countries grew almost twice as much as oil producing ones. What are the reasons behind this diverse yet overall poor performance? We will turn to this question in the coming sections. 


\section{State, Institutions and Development}

Despite the diversity in state structures, resource endowments and economic performance a characteristic shared virtually by all countries in the region (including Turkey and Israel) is the dominant role played by the public sector in the development process (Richards and Waterbury, 1996).

The majority of the states also experimented with the usual sequencing in terms of development models, going through an ISI period (accompanied by land reform) which would be disrupted (usually following an economic and/or political crisis, such as Egypt 1967, 1974; Turkey 1980) and be replaced by an outward oriented development model where the role of state is attempted to be downsized through domestic and external liberalization programs and public sector restructuring.

The first ISI attempts in the region were launched by Turkey in its first five year plan of 1934 emphasizing the establishment of state enterprises in textiles, primary commodities and minerals, ceramic and glass, paper, chemicals and cement, and iron and steel as well as state banks for financing these enterprises. The Turkish model would provide a guide for the other MENA countries and be replicated throughout the region (Richards and Waterbury, 1996). In the oil-rich labor abundant countries, the availability of massive oil rents, or what are termed 'softbudget constraints' allowed the large countries to launch ambitious ISI projects. This led to a proliferation of capital intensive (often turnkey) industries producing protected intermediate and final products for the domestic market. However, tariff protection and credit access was often granted wholesale and no technological upgrading or other performance measures were required as was the case in East Asian countries.

During this period despite the presence of a generally hostile attitude by the state bureaucracy, the private sector in many countries benefited largely from intermediate products supplied by the state enterprises at discounted prices or from other subsidies in the form of cheap credits or foreign exchange ${ }^{\text {iv }}$. One of the characteristics of the ISI era was that during this period the accumulation process was highly dependent on politics rather than markets. The political and economic environment thus created opportunities for wide-ranging rent-seeking behavior within the business community, as businesses competed for the special set of incentives (subsidized credit and foreign exchange, import licenses, etc.) provided by the state. The pre-liberalization ISI era thus gave rise to a narrow distributional coalition between the state bureaucracy and the business community.

Regarding financial and banking sector development the region continues to suffer from a lack of an efficient banking system with long-term credit availability for private investment projects (excluding Israel). Furthermore, the use of state banks for political rent distribution in the form of distributing cheap credits on non-economic grounds manifests itself in the accounts of large "duty losses" of these banks (OECD, 2001; Mitchell, 1999:29-30). In the case of capital market deepening, the money markets are mostly dominated by short term government securities, while capital markets in private securities remain underdeveloped throughout the region.

Moreover, the tax system of the countries in the region has been characterized by the inability or unwillingness of policy makers to implement an efficient and fair tax scheme which, in addition to resulting in a narrow tax base and high tax evasion further contributes to the unequal distribution of tax burden on low-income groups. As a result virtually in all countries in the region the business environment for private firms with no political ties with the state 
bureaucracy is not encouraging. Informal tax traps are common and lack of clear-cut and consistent tax laws result in incorrect assessments of tax obligations (e.g. EIU, 2004).

On the other hand, following independence the survival of these mostly autocratic regimes required distribution of economic rents to a wider group of supporters. Indeed, what is common in the region is that the continuous flow of revenues (mostly from oil rents) has helped postpone economic and political reforms since the region as a whole (excluding Turkey and to some extent Israel) could manage to avoid balance of payments crises that other developing countries faced at the last stage of their ISI experience.

\section{Natural Resources and Development}

After gaining full independence and national sovereignty in the post-colonial era, oil producing MENA countries (which account for about three quarters of the world's proven crude oil reserves and 35 percent of global oil production) reaped the benefits of increasing oil revenues. Once national governments secured control over their oil production and pricing, oil revenues started to flow in cascades. For example, in the case of Saudi Arabia, crude oil revenues increased from around \$10.4 million in 1946 to $\$ 104.2$ billion in 1980 (Owen and Pamuk, 1998:210).

However, this development has led to a Dutch disease with destructive effects on non-oil industrial sectors while retarding economic diversification and growth (Sachs and Warner 2001). Appreciating domestic currency resulting from large-oil related foreign exchange inflows created an unsuitable environment for the development of domestic industries by making non-oil exports less competitive. Furthermore spending on massive construction projects further turned the terms of trade against manufacturing. Another major reason for the misalignment is the pegged or fixed exchange rate regimes adopted in the region as a whole (excluding Turkey) (World Bank, 2003:110). Nabli and Veganzones-Varoudakis (2002) argued that MENA countries experienced overvaluation of more than $20 \%$ a year in their real exchange rates from mid 1970s to 1999 . They also suggest that the exchange rate policy explains losses in competitiveness and in manufactured exports in the region as a whole where real exchange rate overvaluation has decreased the ratio of manufactured goods to GDP ratio by 18 percent a year.

On the other hand, in contrast to the abundance of oil resources, with 5 percent of world's population, MENA countries have only 1 percent of world's renewable fresh water. According to the World Bank the region's per capita supply "stands at only one-third of its 1960 level, and water availability is expected to halve over the next 25 years if the present pattern of use continues" (World Bank, 2004:4). Water shortage means that in addition to the strain of providing clean water to a rapidly increasing population the countries are also increasingly dependent on food imports. Moreover, conflicts over water distribution and sharing have been exacerbated due to a lack of adequate regional conflict resolution mechanisms.

\section{Trade and Development}

Historically, the MENA region was a thriving center of trade both originating within the region and as a crossroads for trade routes between Europe, East Asia, and southern Africa. However, the shift in the balance of power between MENA and Europe over the $17^{\text {th }}$ and $18^{\text {th }}$ centuries and Europe's subsequent industrialization instituted a new pattern of trade that of manufactures exports from Europe in return for primary products and raw materials and led to 
the subsequent decline and decimation of existing manufactures and crafts production the region had enjoyed. During this period, any attempt by the region to industrialize was forcefully prevented (most notably by Britain and France) such as the industrialization efforts by Muhammed Ali in Egypt (Issawi, 1966:363). This not only significantly shifted the pattern of production and trade but also served to disrupt intra-regional trade in agriculture and manufactured goods, which had expanded under the consolidation of the region under the Ottoman rule (Owen, 1993).

More recently, the fortunes of the region (excluding Turkey and Israel) in the post-WW2 period have been dependent on two types of trade. The first one is the inter-regional export of fuels and other primary products (e.g. natural gas, iron phosphates), which during oil price booms reached almost 50 percent of GDP in the oil exporting countries, "with 35 to 40 percent of GDP "spillover" effects for the region as a whole” (Shafik, 1998). The spillover was mainly due to the second, intra-regional trade in labor, which has been a vehicle of transmitting the rents throughout the region, reaching as high as 20 percent of GDP for some countries such as Jordan and around 5-10 percent of GDP or higher for several countries such as Egypt, Syria, Morocco, Jordan, and Tunisia (Galal, 2000).

Both the oil rich labor poor and labor abundant countries have fuel exports that makeup around 85 percent of their total exports as of 2000. The oil poor small states, on the other hand, have successfully diversified their exports whereby manufactures make up around 75 percent of total exports in 2000. Furthermore, Israel and Turkey have highly diversified exports compared to the rest of the region, with Israel emerging as a world leader in high technology exports.

Although regional integration or 'Pan-Arab unity' has been a prominent topic in the region intra-regional trade in MENA has never exceeded 8 percent of exports and is the lowest of any region in the world (Galal, 2000). The lack of diversified production structures has undoubtedly been a hindrance for intra-regional trade, gravity model estimations reveal that MENA countries trade about a third less than otherwise identical countries (Rose, 2002) ${ }^{\mathrm{v}}$.

In order to reverse this trend, the Arab Free Trade Agreement has been established, with eighteen countries signing the agreement in 1997. Furthermore, as a sign of expanding regionalism, in addition to intra-Arab treaties, several MENA countries have signed bilateral association agreements with the EU with others to follow (Fawzy, 2003).

The uncertainty in gains from regional integration is a risk for regimes that are wary of engaging in potentially destabilizing reforms. Moreover, the availability of windfall rents has allowed the regimes to appease domestic constituencies, and prevented the formation of coalitions pressuring integration or other deep structural transformations (Carkoglu et al 1998).

\section{Labor Markets and Human Capital in MENA}

Regarding demographical challenges, the MENA region has the second highest population growth rate in the world after Sub-Saharan Africa exacerbating labor market problems. Although the rate is decreasing in recent years average annual growth in labor force is still expected to be 3.4 percent a year in 2000-2010, which is twice that of other developing countries with adverse effects on per capita incomes (World Bank, 2003:19).

The presence of a disproportionably high share of young population (under 30 constitute almost two thirds of the population on average), low growth rates and lack of skill development has resulted in high unemployment throughout the region. 
It is estimated that 16 MENA countries that represent 60 percent of the regional population need to provide 47 million new jobs between 2002 and 2012 just to keep up with the increasing labor supply (Keller and Nabli, 2002). As a result, the unemployment (and underemployment) rate is quite high in the region and despite underestimated official figures stands at around 15 percent in the Arab countries (UNDP, 2002). Furthermore, since 1981 the labor force has grown faster than population growth and can be expected to increase further with increasing female participation rates.

In the case of oil poor countries, another problem lies in their dependence for job growth on the oil producing countries. As of 1997, for example, foreigners in Kuwait held 99 percent of private sector and 42 percent of public sector jobs. The ratio for the foreign to domestic work force is 90 percent in the UAE 83 percent in Qatar and 69 percent in Saudi Arabia (McMurray, 1999:19).

Regarding human capital, following political independence, the MENA countries faced a daunting task to educate their population with an adult illiteracy of 70 percent in Syria and 85 percent in Algeria, Iraq, and Libya around independence (El-Ghonemy, 1998). The colonial powers had established parallel systems of education and the systemic discrimination in education left the majority of population, especially in rural areas, with dilapidated and low quality public schools while the expatriates, the urban elites and sectors friendly to colonial powers enjoyed high quality educational establishments (El-Ghonemy, 1998).

Since the post independence period MENA countries have invested a high proportion of their GDP towards education and health, and have made remarkable gains on both accounts. Average illiteracy rate has dropped from 60 percent in 1980 to about 43 percent in mid-1990s while enrollment at all levels went up from 31 million to 56 million during the same period (UNDP, 2003). However there is still widespread illiteracy among youth and adults and even higher rates among women and the rural poor. A side effect of the industrialization attempts by the MENA countries was an allocation of resources towards secondary and higher education, which typically have lower social rates of return than primary education. The result has been the oddity of unemployed highly educated workers while having large numbers of illiterate adults and youth (Richards and Waterbury, 1996).

\section{International Conflicts and Socio-Political Instability}

The region has been plagued with ongoing conflicts since the $18^{\text {th }}$ century starting with the decline and the following collapse of Ottoman Empire and erection of colonial regimes. Having borders drawn based on politics by the colonial powers rather than historical, cultural or ethnic backgrounds or social consensus led to subsequent ethnic and religious civil conflicts (for a detailed list of these conflicts, see e.g. Elbadawi, 2005:306-307).

In addition, since 1948 the Middle East has witnessed 4 wars between Israel and several of its Arab neighbors, three wars with Western countries, the full occupation of Iraq and Palestine and partial of Egypt, Lebanon and Syria, extended periods of economic sanctions on Syria, Iraq, Sudan, and Libya, and several coup d'etats instigated from within and outside the region. The Iran-Iraq war alone left around 1 million deaths, 2.5 million refugees with an estimated cost of $\$ 200$ billion. These conflicts have had a direct impact on state structure and overall trajectory of development

The artificial mapping of the region with sovereign borders overlapping with different ethnic and religious groups further fed into the authoritarian state structure thanks to the excuse 
that the survival of the unity of the country is dependent on the suppression of popular demands by different groups.

The majority of publications on socio-political risk and investment/growth relationship find a negative correlation between these variables. Venieris and Gupta 1986, Alesina and Perotti (1996) and others find an inverse relationship between political instability and growth or investment, or savings rate. In addition, Asteriou and Price (2001) found that socio-political instability not only negatively affects the growth rate but also increases its volatility. Similarly, Rodrik finds a significant negative relationship between external shocks and growth in countries where there are latent domestic social conflicts and poor conflict management institutions, as in the case of MENA (Rodrik, 1998).The idea behind the above research is that socio-political unrest and instability disrupts market activities and investment decisions by increasing uncertainty and risk while directing limited resources to non-productive security related expenditures.

As a result (or on the pretext) of non-stop civil/military conflicts the existing regimes have devoted a sizable portion of their budgets to military spending. Average military expenditures to GDP ratio in the region is 6.6 between 1990 and 2004 with a maximum of 21.8 in Kuwait and minimum of 1.8 in Tunisia. Comparatively, the averages were 1.4, 0.5, and 2.5 in Argentina, Mexico, and Malaysia for the same period (Stockholm 2006). Such military spending creates a substantial potential for peace dividend in the region. However, for the peace dividend to materialize, the peace must be 'real and durable, and perceived as such' (Fischer et al., 1993).

\section{Economic Reform in MENA}

Despite the presence of a general consensus among policy makers and economists on the need for reform the question regarding which path to follow remains unanswered. Several countries in the region have embarked on structural adjustment programs (SAPs) under the guidance of IMF and WB. The reforms included standard policy packages by the twin institutions such as fiscal reform (introducing Value Added Taxes (VATs), eliminating state subsidies, increasing transparency in public expenditures), liberalizing trade and capital account, and shifting to more flexible foreign exchange regimes. Despite differences, the countries that enjoyed higher rates of growth since the early 1990s have been those that implemented reform programs (i.e. Egypt, Jordan, Morocco, Tunisia) (Hirata et. al. 2004).

Nevertheless, it is difficult to make a generalized statement on the success of the SAPs in MENA due to credits and debt relieves extended to certain reforming countries based on political considerations during the adjustment period (e.g. Egypt for its support to the first Gulf War) (Gray, 1998).

Despite the implementation of comprehensive trade and financial liberalization programs including tariff reductions, privatization, tax breaks and eased restrictions on foreign ownership, as well as establishment of free trade zones and other incentives to encourage Foreign Direct Investment (FDI), capital flows to the region remain minimal. The region's share of FDI fell to 0.7 percent in 2000 from 2.5 percent in 1980 (Hirata et. al 2004). In addition, most of the capital flowing into the region appears to be in short-term funds. In the case of Turkey, capital account liberalization has exposed it to the uncertainties and instabilities associated with short-term capital flows, which have demonstrated themselves in three major crises in 1994, 2000 and 2001. Furthermore, as shown in the case of banking sector crises and subsequent cost of bank defaults resulting from endemic corruption as well as rent-seeking promoting IMF engineered policies 
(such as 100 percent state insurance on private bank deposits in Turkey) the countries in the region need a major restructuring in their financial systems.

On the other hand, income inequality and poverty rates have increased since the implementation of reform policies (Ali and Elbadawi, 2002; Fergany, 1998). The region had previously enjoyed the lowest incidence of poverty and income inequality of any region in the developing world (Adams and Page, 2003). As a result, only 5.6 percent of the population in the region lived on a less than $\$ 1$ a day benchmark compared with 14.7 percent in East Asia and 28.8 percent in Latin America (Shafik, 1995). Adams and Page (2003) pointed out two statistically and economically significant reasons for this, which are international remittances, and public sector employment and welfare state. The policy of public sector employment and subsidized public services and pricing to generate popular support for the survival of the political regimes appears to be the common element in the region. However, the slow down in growth as well as neoliberal reforms, which scaled back role of the state, have reversed the trend of lowered inequality (Ali and Elbadawi, 2002; Fergany, 1998).

\section{Conclusion and Policy Suggestions}

Contrary to the view that finds "little reason for gradualism" as in World Bank (2003:7), there may arise significant socio-political costs to a "big bang" approach in the region. In a majority of MENA countries, certain sectors and groups of people (i.e. peasantry, civil servants, organized labor) will stand as absolute losers from the reform programs, at least in the short run. Furthermore, the economic and political failures of the past have created an unstable environment pregnant with socio-political fault lines, which are further exposed by slow growth rates, increasing unemployment and increasing income inequality and poverty among different income groups and different regions.

The worsening economic performance has radicalized the divide between urban and rural, secular and Islamist, and ethnic identity groups, and these politicized fault-lines have, in turn, been accompanied by increasing authoritarian governance in the region (Lubeck 1998: 299).

As a result, increasing hegemony of neo-liberal policies along economic liberalization and deregulation of markets may have the opposite effect on political liberalization and consolidation of democracy in the region by further deepening such divisions through increasing economic insecurity and social dislocation among public.

The experiences of MENA countries suggest that historically determined institutional characteristics and the political environment of a country are of crucial importance in determining both the nature of the adjustment process and subsequent economic performance. Given that the market-led, outward-oriented reform programs have not produced the anticipated results so far, there is a continuing debate among economists about the underlying reasons. This article follows the line that developing countries share common structural problems in their institutional settings and that policies that are designed to liberalize their economy (and political/civil life) may also generate serious instabilities without necessarily eliminating the previously existing ones. The existence of strong state hegemony in the form of military, legislative and economic institutions with a lack of clear-cut lines between private and public spheres resulted in lack of democratic accountability and transparency during the design and implementation of reform packages. In addition, previously formed rent-seeking coalitions have 
prevented the implementation of a comprehensive reform program designed according to the needs of the countries in the region.

As a result, instead of removing the state, the neoliberal reform programs helped the state become instrumental in distributing rents to a new group rentiers that make their living from financial rents (Mitchell, 1999:30; Yeldan, 2001; Demir, 2004, 2005). Hence the state(s) "now subsidizes financiers instead of factories, speculators instead of schools” (Mitchell, 1999:31).

The recent experience of MENA countries suggests the state and the institutional infrastructure need to be reformed before embarking on reform programs that may undermine the legitimacy of the state structure and lead to socio-political instabilities. In other words, sequencing of reforms is a must both for the sustainability of the reforms and for their further deepening. The future of the region in terms of economic and political outcomes depends on:

a) Institutional reform in the form of judicial, legal, administrative and prudential regulation including rule of law should be established. In addition, rent-seeking groups need to be controlled if any economic reform is to be successful.

b) Providing social safety nets for the disadvantaged and the losers during transition.

c) Political liberalization including reforming the state and making it democratically accountable rather than populist.

d) Privatization of the ownership or the management of state owned enterprises and public banks are needed to avoid corruption, rent seeking and subsidized credit distribution to a few wealth groups based on political considerations.

e) Boom-bust cycles need to be stabilized especially in the case of resource-rich countries, which are dependent on the changes in the oil markets. As also argued by WB (2003:10), the countries need to establish rules that shield fiscal spending from fluctuations in oil revenues; need to create deposit account for oil revenues to be set aside for future generations, and need to avoid misalignment in exchange rates. This may have solved the "resource curse problem" in the oil rich countries by offering an alternative to investing revenues in non-profitable and noncompetitive domestic investment projects. Secondly, this may also pave the way to avoid currency appreciation and support competitive domestic sectors. Also, this may provide an outlet for inter-generational resource distribution for future generations given the limited supply of oil reserves. ${ }^{\text {vi }}$ 


\section{Endnotes}

${ }^{\mathrm{i}}$ Israel is considered an industrialized country and in that sense is in a separate category than other MENA countries.

${ }^{\text {ii }}$ Our classification here is slightly different than Richards and Waterbury and is meant to highlight export structure, intra-regional labor migration, patterns of industrialization, and dependence on oil revenues. For example, the proven oil reserves of Syria are negligible however it was highly dependent on oil exports for revenues during the ISI period and until today as fuel exports made up 76 percent of total exports in year 2000 .

iii Some recent scholars attempted to explain the lagged performance in the region with the legacy of Islam. Kuran (2004) for example, blames the Islamic waqf or trusts that locked capital into a dysfunctional institution, Islamic inheritance law which dispersed inheritance among multiple heirs, and the individualism of Islamic law as preventing capital accumulation à la Europe. However, the lagging performance of the region vis-à-vis Europe came far too recently on a historical scale to be pinned on the influence of religious (or cultural) institutions. Moreover, as Inalcik (1969) emphasized, Islamic society and law "shaped themselves from the very first in accordance with the ideas and aims of a rising merchant class" (Inalcik 1969: 101). Finally, any attempt to explain the decline in economic performance of the region after $18^{\text {th }}$ century with the religious/cultural factors or institutions should also be able to explain how the same institutions could create the opposite results prior to that date.

${ }^{\text {iv }}$ In Turkey, unlike others, the state assumed a direct role in creating and supporting the development of a national business class Bugra (1994).

${ }^{v}$ The colonial legacy on regionalism warrants greater attention. As Ventura-Dias (1989) argues, colonial powers promoted intra regional trade in Asian countries which allowed "permanent marketing channels to be established" in contrast with both MENA and Latin America, where colonial intervention disrupted intra-regional trade.

${ }^{v i}$ The only country in the region with a definite plan to limit the harmful effects of oil curse is Kuwait that preferred to utilize its oil revenues on investments abroad (Owen and Pamuk, 1998:216). 


\section{Bibliography}

Abed, G. T and Davoodi, H. (2003). Challenges of Growth and Globalization in the Middle East and North Africa. IMF Publications: Washington D.C.

Adams Jr., R.H. and J. Page. (2003). "Poverty, Inequality, and Growth in Selected Middle East and North Africa Countries, 1980-2000.” World Development 31(12): 2027-2048.

Alesina, A., and Perotti, R. (1996). Income Distribution, Political Instability and Investment. European Economic Review, 40(6), 1203-1228.

Ali, A.A. and Elbadawi, I. A. (2002), "Poverty in the Arab World: The Role of Inequality and Growth", in Sirageldin, I. (ed.) Human Capital: Population Economics in the Middle East, pp: 62-95. Cairo: American University in Cairo Press.

Asteriou, D., and Price, S. (2001). Political Instability and Economic Growth: UK Time Series Evidence. Scottish Journal of Political Economy, 48(4), 383-399.

Bairoch, P. (1997). Victoires et déboires II : Histoire économique et sociale du monde du XVIe siècle à nos jours. Paris: Gallimard. Quoted in A. G. Frank (1997), ReOrient, p.12, University of California Press.

Bosworth, B. P. and Collins, S. M. (2003). The Empirics of Growth: An Update Brookings Papers on Economic Activity Vol. 2: 113-79.

Bugra, A. (1994). State and Business in Modern Turkey, Albany: State University of New York Press.

Carkoglu, A., Eder, M., and Kirisci, K. (1998) The Political Economy of Regional Cooperation in the Middle East. London: Routledge Press.

Demir, F. (2004). A Failure Story: Politics and Financial Liberalization in Turkey, Revisiting the Revolving Door Hypothesis. World Development, 32(5), 851-869. (2005). Militarization of the Market and Rent Seeking Coalitions in Turkey.

Development and Change, 36(4): 667-690.

Economic Intelligence Unit (2004). Country Finance Egypt, London: Economic Intelligence Unit.

Elbadawi, I. A. (2005) Reviving Growth in the Arab World, Economic Development and Cultural Change 53(2): 293-326 Routledge.

El-Ghonemy, M. R. (1998). Affluence and Poverty in the Middle East. New York:

Fawzy, S. (2003). “The Economics and Politics of Arab Economic Integration,” in A. Galal and B. Hoekman (eds.) Arab Economic Integration: Between Hope and Reality, pp. 13-37. Washington D.C.: Brookings Institution Press.

Fergany, N. (1998). Human Impact of Capitalist Restructuring in Arab Countries. Journal of Development and Economic Policies 1(1): 9-46.

Fischer, S., Rodrik, D. and Tuma, E. (eds.) (1993). The Economics of Middle East Peace: Views from the Region. Cambridge, MA: MIT Press.

Galal, A. (2000). "Incentives for Economic Integration in the Middle East.” In B.

Hoekman and H. Kheir El-Din, (eds.). Trade Policy Developments in the Middle East and North Africa. pp: 51-67. Washington, D.C.: World Bank Institute.

Gray, M. (1998). Economic Reform, Privatization and Tourism in Egypt. Middle Eastern Studies 34(2): 91-113.

Hirata, H., Sunghyun, H. K., and Kose, M. A. (2004). Integration and Fluctuations: The Case of MENA. Emerging Markets Finance and Trade 40 (6): 48-67. 
Inalcik, H. (1969). Capital Formation in the Ottoman Empire. The Journal of Economic History 29(1): 97-140.

Issawi, C. (1966), The Economic Development of Egypt, 1800-1960, A Book of Readings. In C. Issawi, The Economic History of the Middle East 1800-1914, pp.359374.Chicago: University of Chicago Press.

Keller, J., and Nabli, M. K. (2002), The Macroeconomics of Labor Market Outcomes in the MENA Region over the 1990s. The World Bank. Available at: http://www.worldbank.org/wbi/mdf/mdf4/papers/keller-nabli.pdf

Kuran, T. (2004) Why the Middle East Is Economically Underdeveloped: Historical Mechanisms of Institutional Stagnation, Journal of Economic Perspectives, 18(3), pp. 71-90 .

Lubeck, P. M. (1998). "Islamist Responses to Globalization: Cultural Conflict in Egypt, Algeria, and Malaysia", in Crawford, B. and R. D. Lipschutz (eds.), The Myth of "Ethnic Conflict", pp. 293-319, University of California Press/University of California International and Area Studies Digital Collection, Edited Volume 98.

McMurray, D. (1999). Recent Trends in Middle Eastern Migration, Middle East Report, 211 (Summer): 16-19.

Mitchell, T. (1999). Dreamland: the Neoliberalism of Your Desires. Middle East Report 210: 28-33.

Nabli, M. K. and Veganzones-Varoudakis, M.A. (2002). "Exchange Rate Regime and Competitiveness of Manufactured Exports. The Case of MENA Countries", MENA Working Paper 27, World Bank, Washington D.C.

Organization for Economic Co-operation and Development (OECD). (2001). OECD Economic Surveys: Turkey. Paris: OECD.

Owen, R. and Pamuk, S. (1998). A History of Middle East Economies in the $20^{\text {th }}$ Century. Cambridge, MA: Harvard University Press.

Owen, R.. (1993). The Middle East in the World Economy 1800-1914. New York: St. Martin's Press.

Richards, A. and Waterbury, J. (1996). A Political Economy of the Middle East. Boulder: Westview Press.

Rodrik, D. (1998). "Where Did All the Growth Go? External Shocks, Social Conflicts, and Growth Collapses.” Unpublished paper.

Rose, A. (2002). "Estimating Protectionism through residuals from the gravity model." Unpublished paper.

Sachs, J. D. and Warner, A. M. (2001). Natural Resources and Economic Development: the Curse of Natural resources” European Economic Review 45 pp. 827-838.

Shafik, N. (1995). Claiming the Future: Choosing Prosperity in the Middle East and North Africa. Washington D.C: World Bank.

Shafik, N. (ed). (1998). Prospects for Middle Eastern and North African Economies.

New York: St. Martin's Press.

Stockholm International Peace Research Institute (SIPRI). 2006. Database on Military

Expenditure. Available at: http://www.sipri.org/contents/milap/milex/mex_database1.html, last accessed February, $8^{\text {th }}$, 2008.

UNDP (2003). Arab Human Development Report 2003: Creating A Knowledge Society. United Nations: New York.

United Nations Development Program (UNDP) (2002). Arab Human Development

Report 2002: Creating Opportunities for Future Generations. United Nations. New York. 
Venieris, Y., and Gupta, D. (1986). Income Distribution and Sociopolitical Instability as Determinants of Savings: A Cross-sectional Model. Journal of Political Economy, 94(4), 873883.

Ventura-Dias, V. (1989). "The Structure of South-South trade” in V. Ventura-Dias (ed.) South-South trade: trends, issues, and obstacles to its growth. pp.25-81. New York: Praeger.

World Bank (2004). MENA Regional Brief. The World Bank, Washington D.C.

World Bank (WB) (2003). "MENA Development Report: Trade Investment and

Development in the Middle East and North Africa, Engaging with the World”, The World Bank, Washington D.C.

Yeldan, E. (2001). Kuresellesme Surecinde Turkiye Ekonomisi Bolusum, Birikim ve Buyume (Turkish Economy in the Process of Globalization, Accumulation and Growth). Istanbul: Iletisim Yayinlari. 